\title{
Leadership models and behaviors for sales executives. What drives success and the best results?
}

\author{
Matthias DÜNNWEBER \\ The Bucharest University of Economic Studies, Bucharest, Romania \\ mduennweber@gmail.com \\ Astrid FORTMÜLLER \\ The Bucharest University of Economic Studies, Bucharest, Romania
}

\begin{abstract}
The paper analyses the effectiveness of the best leadership models and behaviours that are used by sales executives. Although, the impact of the most common characteristics and behaviours used in sales have been researched very well, recent research has only very limited results on a comparison of the most successful leadership personality traits and behaviours depending on companies' situation and the context. In this paper we analyse two different situations: dynamic environment and stable environment. The context in this paper refers to the area sales. The paper will provide an explanation of the most successful leadership style used in sales and the characteristics of it and why they are also very useful in a sales process. Additionally, we will analyse the effectiveness of these characteristics in the two different situations of a company and exclusively in the sales context. We argue that the characteristics can be defined as the most effective one in every situation and context. We will develop a theoretical overview that shows clearly the best leadership traits and behaviours for each of the two situations in sales that is based on a literature research. The theoretical frameworks will be adjusted and confirmed with three senior sales executives from three different industries. The results of this paper will provide sales executives useful and easy to understand information about the advantages and disadvantages of the different leadership traits and behaviours depending on the context in and situation.
\end{abstract}

Keywords: leadership models in sales, transformational leadership, characteristics of a sales executive, charismatic leadership behaviour, transactional leadership, five-factor model.

\section{Introduction}

The last few decades have seen the development of various leadership theories. Initially, it was assumed that leaders could only be defined by means of non-learnable character traits (Howell, 2013). This was followed shortly thereafter by the theory that leaders display certain behavioral characteristics (Spillane, 2004). The contingency theory of leadership arose from these two leadership theories, in combination with the assumption that context and situation can also play a role (Foley, 2013).

Since the 1970s, however, the theory of the transformational and transactional leadership style has established itself (Walumbwa and Wernsing 2012). A transformational leader can use his or her demeanor and behavioral traits to manipulate the values of those being led in such a way that the latter do the tasks assigned to them by the leader of their own initiative (Bass and Riggio 2013). In the case of transactional leadership, there is an exchange relationship that leads followers to obey the leader. This exchange may be material, such as a promotion or commission, or immaterial, e.g. positive or negative feedback (Burns, 2015). Various studies that were not conducted in relation to sales but 
were done in a general context have made it clear that, whether in a dynamic environment or in a stable environment, certain characteristics variously influence how a leader is perceived (Shamir and Howell, 1999; Lim and Ployhart, 2004; Hoogh et al., 2005).

Therefore, it is not only important to understand the characteristics of a transformational leader. Successful leaders have to know that their behavior has a different impact on their followers depending on the situation (Hoogh et al., 2005). In the field of sales, several studies have shown that a combination of both leadership styles can achieve the best results. As a successful sales executive, one should be perceived as a transformational executive by one's sales force while still maintaining transactional behavior (Schwepker et al., 2010; MacKenzie et al., 2001). In the following, we will describe the transformational leadership style and the relationship to sales leadership. After this we will clarify which characteristic features executives must demonstrate in a stable environment and in a dynamic environment so that the executive's behavior results in his or her recognition as a transformational leader by their team.

\section{Transformational vs. transactional leadership in sales}

Shannahan et al. (2013) proved that sales forces show a better performance if their subordinator is perceived as a transformational leader (Shannahan et al., 2013). Additional studies show that the combination of both leadership styles is an even more effective way to improve the performance of a sales force (Schwepker et al., 2010; MacKenzie et al., 2001). It can be said that most scientists agree that sales executives that are perceived as transformational leaders are more successful in managing a sales force (Shannahan et al., 2013; Smith, 2012; Schwepker et al., 2010; MacKenzie et al., 2001).

\section{Transformational leadership in sales}

Transformational leaders exude a great deal of charisma. Conger and Kanungo (2010) even use the term charismatic leadership as a synonym for transformational leadership (Conger and Kanungo, 2010). They lead others through enthusiasm and inspiration, passing on their positive thoughts. This ability results in those who are being led regarding their leaders with respect, admiration and trust (Channer and Hope, 2001). Developing a unique environment which offers those who are led both confidence and intellectual stimulation enables them to perform better than expected (Burns, 2005; Bass, 1985).

Sales executives must also strive to create such an environment for salespeople, so that they are able to achieve successes that are above expectations. This is particularly important in Sales, because salespeople have to perform a large number of different tasks to achieve their main goal - in most cases, increased turnover. Partly due to the many emotions involved in a sales process, salespeople are subjected to more stress than is common in other professions. Transformational leaders can handle such situations with ease. It has been proven that the adoption of transformational leadership style reduces stress in those who are led (Cavazotte et al., 2012).

\section{Characteristics of a transformational leader}

The Five-Factor Model offers the currently most popular and most established method of evaluating personal characteristics (Roccas et al., 2002). This model is divided into five personality traits, which are pronounced to various degrees, depending on the individual 
concerned: Extraversion, Agreeableness, Conscientiousness, Neuroticism and Openness to Experience (Goldberg, 1993).

Joyce et al. (2004) have examined correlations pertaining to transformational leaders in relation to these five factors and identified the following correlation coefficients (Joyce et al., 2004): extraversion (0.28), agreeableness (0.21), conscientiousness (0.19), neuroticism (-0.14), and openness to experience (0.23). However, these results from (Joyce et al., 2004) fail to take either the context - in our case this being Sales - or the environmental situation into account. The following findings about the personality traits and transformational leadership will describe that the perceptive of a transformational leader is also related to the situation. It makes a difference if there is a dynamic or stable environment (Hoogh et al., 2005).

\section{Extraversion}

This personality trait concerns interpersonal interaction (Goldberg, 1993). People who have a high Extraversion score exhibit good social skills, are persuasive communicators, and are dominant. They participate strongly in social interactions and are able to talk or make presentations expressively, allowing them to strongly influence others (McCrae and Costa, 1987).

\section{Agreeableness}

This factor allows the pleasantness of a person to be measured (Costa and McCrae, 1992). These people are popular with others and are regarded to be friendly and sympathetic. They are interested in the individual needs of their fellow human beings and are able to look at things from their point of view (Costa and McCrae, 1988). Costa and McCrae (1992)'s definition of Agreeableness includes altruism, trust and collegial behavior (Costa and McCrae, 1992).

\section{Conscientiousness}

Conscientious individuals are reliable, dutiful and performance-oriented. They place great emphasis on maintaining established processes and the observance of regulations. They often seem cautious and pensive to their fellow human beings (McCrae and Costa, 1987; Costa et al., 1991). Differing results from various studies make it unclear whether Conscientiousness correlates positively or negatively with transformational leadership. On the one hand, the leader is acting as a role model and sets high standards by means of reliable, committed behavior, which would suggest a positive correlation (Costa et al., 1991;Diener et al., 1984). On the other hand, it has been proven that careful, thoughtful types of behavior have a negative impact on transformational leadership. The most common explanation for these different results is that it very much depends on the field in which the executives are engaged (Bass, 1985; Costa et al., 1991;Diener et al., 1984).

\section{Neuroticism}

Uncertainty, anxiety and emotion are the key characteristics of neuroticism. According to Bass (1990) and House (1977), courage and confidence are important properties that must be exhibited by a charismatic leader. Several studies were able to prove that a negative correlation to Neuroticism prevails in both stable and dynamic environments. It could even 
be proven that the negative correlation coefficient was reinforced as the dynamic environment became more turbulent and dangerous (Crant and Bateman, 2000).

\section{Openness to experience}

This behavior is attributed to people who are open to new experiences. These individuals are seen to be creative and autonomous, and to think outside the box. They are able to make good use of their visionary imagination by graphically communicating their ideas and values (McCrae and Costa, 1987; McCrae, 1996).

\section{Research methodology}

The content analyses above provided good insights with regard to how important it is that the environment is taken into consideration regardless whether it is dynamic or stable. Following, we need to analyze these findings in our special context which is sales. We will identify if there are any different outcomes if sales executives adapt these characteristics and behaviors.

We chose three sales executives who provided their opinion about different environments in the context sales (Table 1). All participants are familiar with the leadership theories that are important in our research and were also trained to analyze the characteristic traits in the Five-Factor Model. However, a few additional revelations have subsequently been identified in the event these can be assigned to one of the five personality traits. The parties surveyed are leadership staff involved in the sales industry. This makes sure that our context "sales" was taken into consideration in addition to the situation as such. The interviews were conducted individually and notes have been taken. The notes were subsequently assigned to the characteristics of the Five-Factor Model. The goal of this approach was to establish recommendations for a leadership model for sales executives, also taking the environment into consideration.

Table 1. Sample

\begin{tabular}{|l|c|c|c|}
\hline \multicolumn{1}{|c|}{ Features } & $\begin{array}{c}\text { Sales Executive 1 } \\
\text { (SE1) }\end{array}$ & $\begin{array}{c}\text { Sales Executive 2 } \\
\text { (SE2) }\end{array}$ & $\begin{array}{c}\text { Sales Executive 3 } \\
\text { (SE3) }\end{array}$ \\
\hline $\begin{array}{l}\text { No. of years of } \\
\text { professional experience } \\
\text { in sales }\end{array}$ & 6 & 12 & 8 \\
\hline $\begin{array}{l}\text { No. of years in a } \\
\text { leadership position }\end{array}$ & 2 & 5 & 2 \\
\hline Other & $\begin{array}{l}\text { Attended leadership } \\
\text { seminars and } \\
\text { trainings }\end{array}$ & $\begin{array}{l}\text { Worked in 4 } \\
\text { different industries }\end{array}$ & $\begin{array}{l}\text { Worked with 3 } \\
\text { different sales } \\
\text { executives in the } \\
\text { same company }\end{array}$ \\
\hline
\end{tabular}

Source: Authors' own research.

\section{Results and discussion Extraversion}

Since it is always important to salespeople that they are always informed about the market and their competitors, especially in a dynamic environment, a communicative sales executive elicits more trust and respect (SE1). Sales executives are perceived as charismatic if they are as present as frequently as possible in such situations (SE2). Another behavior 
that causes a sales executive to be classified as charismatic is increased attention to the needs of the sales force (SE3).

This is consistent with the assertion that we encountered in the literary research; that executives also in the area of sales are perceived to be more charismatic if they exhibit this behavior (Shamir and Howell, 1999; Ployhart et al., 2001). In sales, Extraversion is one of the most important characteristics, and must be exhibited by sales executives even in a stable environment (SE1). However, this is somewhat more important in both a dynamic environment and in sales than it is in a stable environment (SE2). As the stability of the environment - due to the personal traits which a salesperson must display regardless of the situation - has no effect on subjective perception and this is in any case always important (SE3), the previous hypotheses are somewhat neutralized, but this does not refute the fundamental importance of this behavior in this context.

\section{Agreeableness}

A sales executive whose character is too friendly may also be perceived to be weak. This is particularly true if there is an external threat to sales figures (SE1). This is consistent with the conclusion of Lim and Ployhart (2004): that in the context of a dynamic environment, agreeableness has a negative impact on perceived personal charisma (Lim and Ployhart, 2004).

This hypothesis is further reinforced by the assertion that too much friendliness and sympathy is often perceived as an attempt by the sales executive to distract attention from the instability of the market (SE2). In a fluctuating environment, stabilizing sales figures is more important than the friendliness of sales executive (SE3).

According to Hoogh et al. (2005) Agreeableness has a positive relationship to transformational leadership in a stable environment but not in a dynamic environment (Hoogh et al., 2005). Situations occur in which salespeople are working hard but the figures appear to be stable in any case, since the environment is also stable. In such situations, it is important that executives approach salespeople directly, so that they can better interpret their successes, failures and fears (SE1). Every sale is different and presents different challenges. Managers who address the personal concerns of salespeople are perceived to be charismatic (SE2).

\section{Conscientiousness}

The more comprehensive the work environment relating to customers, products and markets is, the more important oversight and accuracy, as well as exact documentation of this content, becomes (SE1). A sales executive should act here as a role model for his or her salespeople, as the leader who has everything in control (SE2). The salespeople themselves should be able to duplicate this behavior, in order to achieve a high level of self-control (SE3).

In the area of sales, it is important, notwithstanding the stability or instability of the environment that salespeople themselves, and their managers, keep track of detailed customer requirements and markets (SE2). Although, in other contexts, scientists disagree whether conscientiousness has a positive or negative impact on the charisma of leadership in a stable environment (Costa et al., 1991;Diener et al., 1984), according to our surveyed experts, it is always considered an important factor in attributing more charisma to an 
executive. Conger and Kanungo (2010) believe that executives should show little conscientiousness in a dynamic environment (Conger and Kanungo, 2010).

According to our surveyed sales executives, however, this attribute is also important in such situations in order that management may convey security to salespeople through their structured overview.

\section{Neuroticism}

A sales executive must project a high level of self-assurance. Each salesperson also needs to come across to their customers as self-assured and confident. A sales executive must be able to act as a role model for their salespeople (SE1). Should sales executives themselves have no contact with the customers and simply check sales figures, such behavior does not necessarily result in a weakening of the performance of the sales staff, but the executives are then perceived solely as measurers of success and not as a transformational force (SE2). Sales is an area in which success or failure are difficult to predict in advance, it is very important for the sales executive to approach future events with confidence (SE3).

According to the interviews with the sales experts, it is just as important in sales that the sales executive shows no trace of neuroticism. Because of the great uncertainty governing each individual sale, as much in a stable environment as in a dynamic one, a sales executive must not show such traits, regardless of the situation (SE3).

\section{Openness to Experience}

In the age of digitalization and other technological advances, it is important for a sales executive to show enthusiasm for novelty and to transfer this enthusiasm across to his salespeople, who should then transfer the enthusiasm to their potential buyers. In markets with low change, it is also important for a salesperson to stay open towards customer needs and desires that can be in constant flux (SE1).

Independently of the product or the market, it is always important to be able to read the emotions of the salespeople as accurately as possible. Potential complications can be avoided before they arise and the salespeople perceive their leadership as even more charismatic (SE2). The leadership must be as creative and full of ideas in a stable environment as they are in a dynamic one, ushering in the development of new sales strategies that can raise the company above the competition (SE3).

\section{Conclusion}

Sales executives who are perceived by their sales force as transformational leaders positively influence the performance of their sales force (Shannahan et al., 2013; Smith, 2012; Schwepker et al., 2010; MacKenzie et al., 2001). Therefore, it is important for leaders in order to achieve the best results, that their team perceives their leader as a transformational or charismatic leader.

Filling in the gaps, with our literature analysis, we were able to determine that the character qualities have different effects on how a leader is perceived depending on the situation: the more dynamic the environment is, the more important the extraversion characteristic trait becomes (Shamir and Howell, 1999; Ployhart et al., 2001). Agreeableness retains a positive effect on the subjective appearance of a transformational leader only while the environment is stable (Hoogh et al., 2005; Lim and Ployhart, 2004). 
Conscientiousness in a dynamic environment can also lead to the leadership being perceived as less charismatic (Conger and Kanungo, 2010; Bass, 1985; Costa et al., 1991; Diener et al., 1984).

So that we can apply all the results in the right context for sales, we extracted the following character qualities for sales executives from the interviews conducted with experts, taking into account the environmental situation:

PICBE $\mid 785$

Extraversion is more important for sales executives than for general executives. Sales executives should interact with their sales staff in a manner that is relatable and friendly, but in a dynamic or precarious environment, a sales executive must not be perceived as weak. Conscientiousness must always be present, as it is easy in sales to lose sight of the big picture that has a negative effect on the perceived charisma. Sales executives must not show any behavior of neuroticism. It is even more important in sales to be open to experience in order to act speedily with changes in the market and new customer desires.

\section{References}

Bass, B.M. (1985). Leadership: Good, better, best. Organizational Dynamics, 13(3), 26-40.

Bass, B.M., and Avolio, B.J. (1990). Developing Transformational Leadership: 1992 and Beyond. Journal of European Industrial Training, 14(5), 21-27.

Bass, B.M., and Stogdill, R.M. (1990). Bass \&amp; Stogdill's handbook of leadership: theory, research, and managerial applications Bass and Stogdill's handbook of leade. New York: Free Press.

Bass, B.M., and Riggio, R.E. (2013). Transformational leadership. New York: Psychology Press.

Binning, J.F., Conger, J.A., and Kanungo, R.N. (1990). Charismatic Leadership: The Elusive Factor in Organizational Effectiveness. Administrative Science Quarterly, 35(4), 159161.

Bono, J.E., and Judge, T.A. (2004). Personality and Transformational and Transactional Leadership: A Meta-Analysis. Journal of Applied Psychology, 89(5), 901-910.

Burns, J. M. (2005). Leadership. Leadership, 1(1), 11-12. doi:10.1177/1742715005049347

Cavazotte, F., Moreno, V., and Hickmann, M. (2012). Effects of leader intelligence, personality and emotional intelligence on transformational leadership and managerial performance. The Leadership Quarterly, 23(3), 443-455.

Channer, P., and Hope, T. (2001). Emotional Impact. New York: Palgrave.

Conger, J.A., and Kanungo, R.N. (2010). Charismatic Leadership: the elusive factor in organizational effectiveness. San Francisco, CA: Jossey-Bass .

Costa, P.T., and Mccrae, R.R. (1988). From catalog to classification: Murray's needs and the five-factor model. Journal of Personality and Social Psychology, 55(2), 258-265.

Costa, P.T., Mccrae, R.R., and Dye, D.A. (1991). Facet Scales for Agreeableness and Conscientiousness: A Revision of the NEO Personality Inventory. Personality and Individual Differences, 12(9), 887-898.

Costa, P.T., and Mccrae, R.R. (1992). Normal personality assessment in clinical practice: The NEO Personality Inventory. Psychological Assessment, 4(1), 5-13.

Crant, J.M., and Bateman, T.S. (2000). Charismatic leadership viewed from above: the impact of proactive personality. Journal of Organizational Behavior, 21(1), 63-75.

Diener, E., Larsen, R.J., and Emmons, R.A. (1984). Person Situation interactions: Choice of 
situations and congruence response models. Journal of Personality and Social Psychology, 47(3), 580-592.

Foley, M. (2013). Doing leadership: Types, styles, and contingency. Political Leadership, 3157.

Goldberg, L.R. (1993). The structure of phenotypic personality traits. American Psychologist, 48(1), 26-34.

Graziano, W.G., and Eisenberg, N. (1997). Agreeableness. Handbook of Personality Psychology, 795-824.

Hoogh, A.H., Hartog, D.N., and Koopman, P.L. (2005). Linking the Big Five-Factors of personality to charismatic and transactional leadership; perceived dynamic work environment as a moderator. Journal of Organizational Behavior, 26(7), 839-865. doi:10.1002/job.344

House, R.J. (1977). A 1976 theory of charismatic leadership. Toronto: Faculty of Management Studies, University of Toronto.

Howell, J.P. (2013). Snapshots of great leadership. New York: Routledge.

Lim, B., and Ployhart, R.E. (2004). Transformational Leadership: Relations to the FiveFactor Model and Team Performance in Typical and Maximum Contexts. Journal of Applied Psychology, 89(4), 610-621.

Mackenzie, S.B., Podsakoff, P.M., and Rich, G.A. (2001). Transformational and Transactional Leadership and Salesperson Performance. Journal of the Academy of Marketing Science, 29(2), 115-134.

Mccrae, R.R., and Costa, P.T. (1987). Validation of the five-factor model of personality across instruments and observers. Journal of Personality and Social Psychology, 52(1), 8190.

Mccrae, R.R. (1996). Social consequences of experiential openness. Psychological Bulletin, 120(3), 323-337.

Ployhart, R.E., Lim, B., and Chan, K. (2001). Exploring Relations Between Typical And Maximum Performance Ratings And The Five Factor Model Of Personality. Personnel Psychology, 54(4), 809-843.

Podsakoff, P.M., Mackenzie, S.B., Moorman, R.H., and Fetter, R. (1990). Transformational leader behaviors and their effects on followers' trust in leader, satisfaction, and organizational citizenship behaviors. The Leadership Quarterly, 1(2), 107-142.

Roccas, S., Sagiv, L., Schwartz, S.H., and Knafo, A. (2002). The Big Five Personality Factors and Personal Values. Personality and Social Psychology Bulletin, 28(6), 789-801.

Schwepker, C.H., and Good, D.J. (2010). Transformational Leadership and its Impact on Sales Force Moral Judgment. Journal of Personal Selling and Sales Management, 30(4), 299-318.

Shamir, B., and Howell, J.M. (1999). Organizational and contextual influences on the emergence and effectiveness of charismatic leadership. The Leadership Quarterly, 10(2), 257-283.

Shannahan, K.L., Bush, A.J., and Shannahan, R.J. (2012). Are your salespeople coachable? How salesperson coachability, trait competitiveness, and transformational leadership enhance sales performance. Journal of the Academy of Marketing Science, 41(1), 40-54.

Smith, B., Andras, T.L., and Rosenbloom, B. (2012). Transformational Leadership: Managing the Twenty-First Century Sales Force. Psychology and Marketing, 29(6), 434-444. 
Spillane, J.P., Halverson, R., and Diamond, J.B. (2004). Towards a theory of leadership practice: a distributed perspective. Journal of Curriculum Studies, 36(1), 3-34.

Walumbwa, F.O., and Wernsing, T. (2012). From Transactional and Transformational Leadership to Authentic Leadership. Oxford Handbooks Online.

Woodman, R.W., Sawyer, J.E., and Griffin, R.W. (1993). Toward a Theory of Organizational Creativity. The Academy of Management Review, 18(2), 293.

PICBE | 787 